\title{
STRATEGI PENGELOLAAN SAMPAH DI TEMPAT PENGOLAHAN SAMPAH TERPADU KEBOANSIKEP KECAMATAN GEDANGAN KABUPATEN SIDOARJO TAHUN 2017
}

Deavita Resaningtyas, Mamik, Setiawan

\begin{abstract}
ABSTRAK
Upaya Pemerintah pusat untuk meminimalisir sampah didukung penuh oleh Kabupaten Sidoarjo. Program yang telah dilaksanakan adalah pembangunan TPST (Tempat Pengolahan Sampah Terpadu).TPST Keboansikep merupakan TPST skala menengah yang dikelola oleh KSM (Kelompok Swadaya Masyarakat) Bumi Lestari. Tujuan penelitian ini untuk menentukan strategi pengelolaan sampah di TPST Keboansikep.

Jenis penelitian deskriptif kualitatif yaitumenggambarkan fakta-fakta pengelolaan sampah rumah tangga di Desa Keboansikep. Metode yang digunakan yaitu Analisis SWOT.

Hasil matriks IFAS skor tertinggi berada pada kekuatan dan sedangkan matriks EFAS berada di peluang. sehingga dapat disimpulkan pada diagram analisi SWOT masuk ke dalam katagori kuadran I yaitu mendukung startegi agresif.

Simpulan ditentukan strategi pengelolaan sampah di TPST Keboansikep(1) Mengadakan pelatihan atau pendidikan pembuatan daur ulang dari sampah kepada warga, (2) Menyediakan atau mengadakan pewadahan sampah secara terpilah baik sampah basah maupun sampah kering di titik-titik tertentu, (3) Membentuk kader lingkungan, (4) Meningkatkan kualitas SDM dengan mengikuti program Pelatihan yang akan dilaksanakan oleh DLHK, (5) Bekerja sama dengan pemerintah desa untuk mengadakan sosialisasi kepada warga untuk menyadarkan masyarakat akan perilaku membuang sampah dan memilah sampah, dan (6) Membuat sarana pengolahan air lindi sederhana, (7) Membuat papan pengumumam/ mading di TPST Keboansikep. Saran bagi pengelola adalah pelatihan/sosialisasi pengolahan sampah.

Kata kunci : SWOT, Pengelolaan sampah
\end{abstract}

\section{PENDAHULUAN}

Menurut Menteri Lingkungan Hidup pada tahun 2011 diperkirakan jumlah sampah di Indonesia mencapai 80.000 ton setiap harinya dari 230 kota di Indonesia. Namun dari jumlah tersebut hanya 34.000 ton sampah yang terangkut dan dikelola dengan layak oleh Pemerintah. Sampah merupakan virus bagi manusia. Dalam kesehariannya manusia tak lepas dengan sampah. Hampir di setiap aktivitasnya selalu menghasilkan sampah. Volume sampah tak dapat dihentikan akan tetapi harus dikurangi, diminimalisir atau dikelola dengan baik.Berdasarkan data BAPEDDA Sidoarjo pada tahun 2014 jumlah volume produksi sampah adalah 4.517 m3, sedangkan pada tahun 2015 dan 2016 adalah $4.599 \mathrm{m3}$, dan 5.404 $\mathrm{m} 3$. Jumlah sampah yang dihasilkan pada tahun 2016 sebesar $5.404 \mathrm{~m} 3 /$ hari dengan komposisi sampah yang tidak diolah sebesar $2.511 \mathrm{~m} 3 /$ hari atau $58,28 \%$, yang di kelola TPS 3R/ TPST adalah sebesar $553 \mathrm{m3} /$ hari atau 12,84\%, sampah yang dikelola bank sampah 72 $\mathrm{m} 3 /$ hari atau $1,67 \%$ sedangkan sisanya langsung di buang ke TPA. Upaya pemerintah Kabupaten Sidoarjo untuk mengurangi volume sampah dilakukan sejak dari sumbernya. Dalam 3 tahun terakhir ini DLHK (Dinas Lingkungan Hidup dan Kebersihan) Sidoarjo ikut mendukung pembangunan TPST dan TPS3R. Berdasarkan data yang ada jumlah TPS $3 R$ yang telah beroperasi di Sidoarjo adalah 70 unit, sedangkan TPST baik sekala kawasan maupun skala menengah berjumlah 16 unit. TPST keboansikep berdiri pada tahun 2005 dan baru mulai beroperasi pada tahun 2008. Pengelola TPST tersebut adalah KSM (Kelompok Swadaya Masyarakat) Bumi Lestari. Adanya TPST ini juga mendukung program pemerintah dalam mengentasan kemiskinan karena tersedianya lapangan kerja bagi pengelola sampah. Berdasarkan observasi yang dilakukan rata-rata pengelola sampah 
merupakan masyarakat grass root (miskin). Rata-rata setiap harinya volume di TPST dari tahun 2013-2015 mencapai 4-5 ton akan tetapi tahun 2016 mengalami peningkatan berjumlah 5-6 ton. Sampah tersebut berasal dari 4600 KK, sekolah, warung/toko dan swalayan. Rata-rata Persentase sampah organik, anorganik dan residu setiap harinya adalah $55,6 \%$ residu, $27,7 \%$ organik dan $16,7 \%$ non organik. Artinya masih banyak sampah yang dibuang ke TPA. Di TPST ini sampah organik diolah dan kemudian di jual. Berdasarkan realita diatas, penulis tertarik untuk mengetahui lebih lanjut tentang pengelolaan sampah yang ada di Kelurahan Keboansikep dengan menggunakan analisis SWOT yaitu dengan cara membandingkan kondisi pengelolaan sampah dengan indikator Strength (kekuatan), Weaknesses (kelemahan) dan Opportunity (kesempatan) dan Threats (ancaman), dengan judul penelitian "Strategi Pengelolaan Sampah di TPST Keboansikep Kecamatan Gedangan Kabupaten Sidoarjo".

\section{METODE PENELITIAN}

Jenis penelitian adalah deskriptif kualitatif yaitu suatu metode penelitian yang dilakukan dengan tujuan utama untuk menggambarkan tentang suatu keadaan secara obyektif, yang dilakukan dengan survei atau pengamatan lapangan secara langsung terhadap beberapa obyek (variabel) yang diteliti.Lokasi Penelitian dilakukan di TPST Keboansikep Kecamatan Gedangan Kabupaten Sidoarjo. Penelitian dilakukan pada bulan Juni 2017. Dalam penelitian ini peneliti menggunakan metode purposive sampling. Metode penarikan sampel hanya mengambil orang-orang yang dianggap mengetahui atau pakar pengelolaan sampah, arti pakar adalah pihak-pihak yang memahami dan mengeti benar tentang pengelolaan sampah di TPST Keboansikep. Sampel adalah wakil dari tiap-tiap stakeholder yang terkait dengan pengelolaan sampah di TPST Keboansikep baik pemerintah maupun masyarakat.

1. Informasi Kunci

a. Kepala KSM Bumi Lestari b. Kepala Bagian Kebersihan Dinas Lingkungan Hidup dan Kebersihan Kabupaten Sidoarjo.

c. Sekretaris Desa Keboansikep

2. Informasi Pendukung

a. Ketua PKK

b. Koordinator Lapangan

c. bendahara desa keboansikep dan ksm bumi lestari

Teknik pengumpulan data dilakukan melalui 3 cara yaitu observasi, wawancara dan dokumentasi. Proses analisis data dalam penelitian ini diawali dengan metode pengumpulan data yaitu observasi, wawancara, dan dokumentasi. Data yang terkumpul ditelah dan di klasifikasi selanjutnya dilakukan praanalisis secara deskriptif kualitatif.

Pemrosesan data penelitian dilakukan melalui pengelompokan data hasil penelitian berdasarkan kategori-kategori yang telah ditentukan. Kategori pengelompokan data tersebut di dasarkan kategori; 1) kekuatan (Strength), 2) kelemahan (Weaknesses), 3) peluang (Opportunity), dan 4) ancaman (Threats) sehubungan dengan pengelolaan sampah di Keboansikep.

Setelah semua data katagori terkumpul kemudian masukkan ke dalam matrik IFAS dan EFAS tentukan bobot dan rattingnya kemudian masukkan ke dalam model matrik SWOT agar dapat memperoleh strategi pengelolaan sampah dengan optimal

\section{HASIL DAN PEMBAHASAN Sistem Pengelolaan Sampah}

Berdasarkan SNI 3242-2008 tentang Tata Cara Pengelolaan Sampah di Permukiman terbagi menjadi dua yaitu Pengelolaan Sampah non operasional dan operasional. Pengelolaan Sampah Non operasional terdiri atas sistem kelembagaan/ organisasi, sistem pembiayaan/ retribusi, sistem regulasi/peraturan dan sistem peran serta masyarakat. Sedangkan Pengelolaan Sampah operasional terdiri atas pewadahan, pengumpulan, Pengolahan dan pengangkutan. Berdasarkan hasil observasi sistem pengelolaan sampah non operasinal di Desa Keboansikep termasuk baik dengan nilai 14. Berdasarkan penilaian observasi TPST Keboansikep dalam pengelolaan 
sampah secara operasinal dikatagorikan baik dengan nilai 11.TPST Keboansikep memiliki luas lahan $\pm 800 \mathrm{~m}^{2}$. TPST Keboansikep dikelola oleh KSM Bumi lestari. KSM Bumi Lestari adalah Kelompok Swadaya Masyarakat yang dibentuk oleh kepala desa Keboansikep dan di setujui oleh masyarakat Keboansikep untuk mengurus sampah rumah tangga di wilayah Keboansikep. TPST Keboansikep langsung mengangkut sampah dari sumbernya seperti sampah di tiap-tiap rumah, sekolah, pasar/toko, swalayan dan tempat makan. Pengambilan sampah dari sumber ke TPST dilakukan setiap hari. Ritasi pengangkutan residu sampah ke TPA juga dilakukan setiap hari. Jumlah kendaraan pengangkut sampah (gerobak) sebanyak 8 gerobak. Masing-masing gerobak sampah dapat menampung sampah sebanyak 250-300 kg. Jumlah tenaga kerja sebanyak 18 orang. Jumlah penggeledek sampah di TPST sebanyak 10 orang sedangkan pemilah 4 orang, satpam 1 dan pengurus inti 3. Jumlah tenaga yang kurang memadai di TPST ini mengakibatnya masih banyaknya residu sampah yang di buang ke TPA. Peran serta masyarakat keboansikep terhadap pengelolaan sampah terbilang pasif dimana masyarakat hanya berperan dalam pembayaran iuran sampah dan penentuan kepengurusan KSM Bumi Lestari. Sedangkan masyarakat tidak terlibat dalam kegiatan teknik operasianal pengelolaan sampah.

\section{Kekuatan dan Kelemahan}

Berdasarkan hasil wawancara dan observasi lapangan telah diketahui ada 5 kekuatan dan 5 kelemahan kemudian dianalisis ke dalam matriks IFAS.

Tabel 1

Matriks Internal Strategic Factors Analysis Summary

\begin{tabular}{|c|c|c|c|c|}
\hline No & Faktor Strategi & Bobot & Rating & Skor \\
\hline $\mathbf{I}$ & Kekuatan (Strength) & & & \\
\hline 1 & Adanya sumber sampah & 10,5 & 2 & 0,21 \\
\hline 2 & Mengakses informasi mudah & 7,9 & 2 & 0,16 \\
\hline 3 & $\begin{array}{l}\text { Dukungan penuh dari Desa } \\
\text { Keboansikep }\end{array}$ & 12,7 & 4 & 0,51 \\
\hline 4 & Adanya regulasi tentang Sampah & 12,1 & 4 & 0,49 \\
\hline \multirow[t]{2}{*}{5} & Sarana dan prasarana memadai & 10,5 & 3 & 0,32 \\
\hline & & & & 1,69 \\
\hline II & \multicolumn{4}{|l|}{ Kelemahan (Weaknesses) } \\
\hline 1 & $\begin{array}{l}\text { Jumlah Tenaga Kerja kurang } \\
\text { memadai }\end{array}$ & 12,1 & 3 & 0,36 \\
\hline 2 & $\begin{array}{l}\text { Tidak adanya pengolahan air lindi } \\
\text { (bau sampah) }\end{array}$ & 12,7 & 2 & 0,25 \\
\hline 3 & Kualitas SDM rendah & 6,3 & 3 & 0,19 \\
\hline 4 & $\begin{array}{l}\text { Kurang adanya rasa tanggung } \\
\text { jawab terdapat tupoksinya }\end{array}$ & 11,5 & 2 & 0,23 \\
\hline 5 & Manajeman lemah & 3,7 & 3 & 0,11 \\
\hline & & & & 1,14 \\
\hline
\end{tabular}


Skor pada Kekuatan (Strength) sebesar 1,69 sedangkan Kelemahan (Weaknesses) sebesar 1,14. Maka apabila S-W untuk menentukan sumbu $X$ yaitu 0,55 . Dari hasil matriks IFAS skor tertinggi hingga terendah terkait kekuatan adalah dukungan penuh dari pemerintah Desa, adanya regulasi terkait pengelolaan sampah, sarana prasarana yang memadai, adanya sumber sampah dan mudahnya mengakses informasi. Dari ke 5 kelemahan tersebut urutan skor tertinggi sampai terendah yaitu jumlah tenaga kerja yang belum memadai, tidak adanya pengolahan air lindi, kualitas SDM rendah, rasa tanggung jawab yang kurang, dan lemahnya manajemen.

\section{Peluang dan Ancaman}

Berdasarkan hasil wawancara dan observasi lapangan telah diketahui ada 5 peluang dan 4 ancaman kemudian dianalisis ke dalam matriks. Dari matriks EFAS (External Strategic Factors Analysis Summary) didapat Skor pada Peluang (Opportunity) sebesar 1,64 sedangkan Ancaman (Threats) sebesar 1,25. Maka apabila P-A untuk menentukan sumbu $Y$ yaitu 0,19. Dari hasil matriks EFAS skor tertinggi ke terendah yaitu pengadaan mesin conveyer dan 200 bak sampah pada tahun 2017, penjualan sampah anorganik, organisasi persatuan pengelolaan sampah terpadu, program pelatihan bagi KSM di Sidoarjo, dan penjualan kompos. Berdasarkan hasil matriks EFAS skor tertinggi ke terendah yaitu rendahnya kesadaran masyarakat akan lingkungannya, belum adanya sanksi yang tegas dan mengikat dalam setiap pelanggaran terkait dengan sampah, pertambahan jumlah penduduk, dan lokasi TPST yang dekat dengan pemukiman.

Tabel 2

Matriks External Strategic Factors Analysis Summary

\begin{tabular}{|c|c|c|c|c|}
\hline No & Faktor Strategi & Bobot & Rating & Skor \\
\hline $\mathbf{I}$ & \multicolumn{4}{|l|}{ Peluang (Opportunity) } \\
\hline 1 & Penjualan sampah anorganik & 9,6 & 4 & 0,38 \\
\hline 2 & Penjualan kompos & 8,2 & 1 & 0,08 \\
\hline 3 & $\begin{array}{l}\text { Adanya program DLHK untuk } \\
\text { memberikan pelatihan kepada } \\
\text { KSM di Sidoarjo }\end{array}$ & 14,3 & 2 & 0,29 \\
\hline 4 & $\begin{array}{l}\text { Adanya organisasi persatuan } \\
\text { pengelolaan sampah terpadu }\end{array}$ & 10,7 & 3 & 0,32 \\
\hline \multirow[t]{2}{*}{5} & $\begin{array}{l}\text { Pengadaan mesin conveyer dan } \\
200 \text { bak sampah pada tahun } \\
2017 \text { dari Desa Keboansikep }\end{array}$ & 14,3 & 4 & 0,57 \\
\hline & & & & 1,64 \\
\hline II & \multicolumn{4}{|l|}{ Ancaman (Threats) } \\
\hline 1 & $\begin{array}{l}\text { Lokasi berada dekat dengan } \\
\text { pemukiman }\end{array}$ & 4,8 & 2 & 0,10 \\
\hline 2 & Peningkatan jumlah penduduk & 11,9 & 2 & 0,24 \\
\hline 3 & $\begin{array}{l}\text { Kesadaran masyarakat terhadap } \\
\text { lingkungan masih } \\
\text { Rendah }\end{array}$ & 13,1 & 4 & 0,52 \\
\hline 4 & $\begin{array}{l}\text { Belum adanya sanksi yang tegas } \\
\text { dan mengikat dalam setiap } \\
\text { pelanggaran terkait dengan } \\
\text { sampah }\end{array}$ & 13,1 & 3 & 0,39 \\
\hline & & & & 1,25 \\
\hline
\end{tabular}




\section{Strategi Pengelolaan Sampah}

Berdasarkan hasil matriks IFAS skor tertinggi berada pada kekuatan dan sedangkan matriks EFAS berada di peluang. sehingga dapat disimpulkan pada diagram analisi SWOT masuk ke dalam katagori kuadran I yaitu mendukung startegi agresif. Kuadran I merupakan situasi yang sangat menguntungkan. Organisasi tersebut memiliki peluang dan kekuatan sehingga dapat memanfaatkan peluang dan kekuatan yang ada. Strategi yang harus diterapkan dalam kondisi ini adalah mendukung kebijakan pertumbuhan yang agresif.

\section{a. Strategi S-O}

memanfaatkan seluruh kekuatan untuk merebut dan memanfaatkan peluang sebesar-besarnya. Dengan adanya dukungan pemerintah desa secara penuh dapat digunakan untuk mengadakan pelatihan atau pendidikan kepada warga untuk daur ulang sampah, Menyediakan atau mengadakan pewadahan sampah secara terpilah baik sampah basah maupun sampah kering di titik-titik tertentu.

\section{b. Strategi S-T}

Menggunakan kekuatan yang dimiliki perusahaan untuk mengatasi ancaman mengadakan sosialisasi kepada warga akan perilaku membuang sampah dan memilah sampah.

c. Strategi W-O

Manfaatan peluang yang ada dengan meminimalkan

kelemahan.Meningkatkan kualitas SDM dengan mengikuti program Pelatihan yang akan dilaksanakan oleh DLHK.

\section{d. Strategi W-T}

meminimalkan kelemahan yang ada serta menghindari ancaman. Membuat sarana pengolahan air lindi sederhana dan Membuat mading/papan pengumuman.

\section{KESIMPULAN}

Berdasarkan hasil penelitian diatas dapat dijabarkan kesimpulan sebagai berikut:

1. Strategi pengelolaan sampah di TPST Keboansikep adalah a) Mengadakan pelatihan atau pendidikan pembuatan daur ulang dari sampah kepada warga keboansikep, b) Menyediakan atau mengadakan pewadahan sampah secara terpilah baik sampah basah maupun sampah kering di titik-titik tertentu, c) Membentuk kader lingkungan, d) Meningkatkan kualitas SDM dengan mengikuti program Pelatihan yang akan dilaksanakan oleh DLHK, e) Bekerja sama dengan pemerintah desa untuk mengadakan sosialisasi kepada warga untuk menyadarkan masyarakat akan perilaku membuang sampah dan memilah sampah, dan f) Membuat sarana pengolahan air lindi sederhana, g) Membuat papan pengumumam/ mading di TPST Keboansikep

2. Sistem pengelolaan Sampah di TPST keboansikep secara non operasinal termasuk katagori baik dengan nilai 14 , sedangan sistem pengelolaan sampah secara operasinal juga terkatagori baik dengan hasil 11.

3. Kekuatan (Strengths) dari dalam pengelolaan sampah di TPST Keboansikep berdasarkan skor tertinggi hingga terendah adalah dukungan penuh dari pemerintah Desa, adanya regulasi terkait pengelolaan sampah, sarana prasarana yang memadai, adanya sumber sampah dan mudahnya mengakses informasi.

4. Kelemahan (Weaknesses) berasal dari dalam TPST keboansikep yang mungkin bisa menghambat kegiatan pengelolaan sampah berdasarkan urutan skor tertinggi sampai terendah yaitu jumlah tenaga kerja yang belum memadai, tidak adanya pengolahan air lindi, kualitas SDM rendah, rasa tanggung jawab yang kurang, dan lemahnya manajemen.

5. Peluang (Opportunity) yang dimiliki oleh TPST keboansikep yang berasal dari luar dari skor tertinggi ke terendah yaitu pengadaan mesin conveyer dan 200 bak sampah pada tahun 2017, penjualan sampah anorganik, organisasi persatuan pengelolaan 
sampah terpadu, program pelatihan bagi KSM di Sidoarjo, dan penjualan kompos.

\section{SARAN}

1. Bagi Dinas Lingkungan Hidup dan Kebersihan

a. Melakukan monitoring dan evaluasi terkait dengan kinerja pengelolaan sampah di TPST.

b. Memberikan pelatihan/seminar kepada pengelola sampah di Sidoarjo.

2. Bagi Desa Keboansikep

a. Memberikan sosialisasi kepada masyarakat terkait perilaku membuang sampah dan memilah sampah.

b. Menyediakan tempat sampah terpisah baik sampah basah dan sampah kering di titik-titik tertentu.

c. Membentuk kader lingkungan

d. Melakukan monitoring dan evaluasi terkait dengan kinerja pengelolaan sampah di TPST.

\section{DAFTAR PUSTAKA}

Abdul, dan Susanti, S, 2012. Analisis SWOT tentang pengelolaan sampah di kawasan Pemukiman Suku Bajo Torosiaje Kecamatan Popayato Kabupataen Pohuwato.

Budijanto Didik \& Prajogo disunting Surasri Siti \& Setiawan 2005. Metodologi Penelitian. Surabaya. Unit Penelitian dan Pengabdian Masyarakat Politeknik Kesehatan Surabaya : 22.

Candra, Budiman, 2012. Pengantar Kesehatan lingkungan. Jakarta. Buku Kedokteran EGC : 168-182.

Damanhuri, E dan Padmi, T, 2010. Pengelolaan Sampah. Bandung. ITB :18-24.

Faizah, 2008. Pengelolaan Sampah Rumah Tangga Berbasis Masyarakat (Studi Kasus Di Kota Yogyakarta) : 27-56.

Libiyanti, R, 2012. Pengelolaan Sampah Berbasis Masyarakat (Studi Kasus : Kelurahan Pleburan Kecamatan Semarang Selatan, Kota Semarang).
Notoatmodjo, Soekidjo, 2010. Metodologi Penelitian Kesehatan. Jakarta. Rineka Cipta : 35-36.

Nurpratiwiningsih, L. Suhandini, $P$. Banowati, E. 2015. Pengelolaan Sampah Rumah Tangga Berbasis Masyarakat Di Kelurahan Sekaran Kecamatan Gunungpati Kota Semarang.

Peraturan Menteri Pekerjaan Umum Republik Indonesia Nomor 03/Prt/M/2013 Tentang Penyelenggaraan Prasarana Dan Sarana Persampahan Dalam Penanganan Sampah Rumah Tangga Dan Sampah Sejenis Sampah Rumah Tangga.

Purwendro, S dan Nurhidayat, 2006. Mengolah Sampah Untuk Pupuk Pestisida organik. Jakarta, Penebar Swadaya : 3.

Rahman, A, 2013. Sampah Rumah Tangga ( Studi Kasus Di Kelurahan Pasar Sarolangun ) : 215-220.

Rangkuti, F, 2015. Teknik Membedah Kasus Bisnis Analisis SWOT. Jakarta, PT Gramedia Pustaka Utama : 1-38

Soemirat, Juli, 2011. Kesehatan lingkungan. Bandung. Gadjah Mada University : 178-185.

Standart Nasional Indonesia (SNI) 192454-2002 Tentang Tata Cara Teknik operasional Pengelolaan Sampah Perkotaan.

Standart Nasional Indonesia (SNI) 193983-1995 tentang Spesifikasi Timbulan Sampah untuk Kota Kecil dan Sedang

Standart Nasional Indonesia (SNI) 32422008 tentang Pengelolaan Sampah di Pemukiman.

Undang-Undang Republik Indonesia Nomor 18 Tahun 2008 Tentang Pengelolaan Sampah.

Wibowo, EH, 2010. Perilaku Masyarakat Dalam Mengelola Sampah Permukiman Di Kampung Kamboja Kota Pontianak.

Waluyo, L. 2007. Mikrobiolgi Umum Edisi Revisi. Malang. UMM Press : 31-330. 